\title{
OXIDATIVE STRESS EFFECTS OF HEROIN AND CANNABIS ADDICTION IN EGYPTIAN POPULATION SAMPLE
}

\author{
$\mathcal{B} \mathcal{Y}$ \\ Nahla E. Nagy; Osama A. Mohammed"; Ahmed S. Doghish ${ }^{* *}$ and Doaa A. El Morsi ${ }^{* * *}$ \\ Psychiatry; Pharmacology* Departments, Faculty of Medicine - Ain Shams Univ.; Biochemistry Department ${ }^{* *}$ \\ Faculty of Pharmacy, Al-Azhar Univ. and Forensic Medicine \& Clinical Toxicology Department ${ }^{* * *}$ Mansoura Univ., Egypt
}

\begin{abstract}
Addiction is one of the world's major health problems with large direct health costs (psychiatric and physical). The present study aimed to investigate the oxidative stress effects of heroin and cannabis addiction and their impact on the immune system. Eighty four subjects (60 addicts and twenty four control subjects); their ages ranged from 18 to 38 years were studied. Each subject was screened for detection of substance of abuse in urine and detection of cytokines; interleukins (IL2 and IL6) and reactive oxygen species (ROS) (reduced glutathione; thiobarbituric acid reactive substances \{TBARS\} and protein oxidation) in blood after taking informed consent. The results revealed a significant decrease in serum IL-2 and in protein thiols level in males and females heroin and cannabis addicts $(p<0.001)$. While, there were significant increase in both TBARS and protein oxidation in heroin and cannabis male and female addicts in comparison to the control group. It could be concluded that heroin and cannabis addiction had deleterious effects on the immune system through their effects on oxidative stress and release of ROS.
\end{abstract}

Keywords: Addiction, oxidative stress; interleukins, lipid peroxidation, protein oxidation, ROS.

\section{INTRODUCTION}

Addiction is a major health problem with large health impacts (psychiatric and physical) as well as massive indirect costs to society in terms of crime, loss of earnings and productivity and social damage (Oliveira et al., 2013a).

One of the negative consequence caused by addiction is impaired ability to refrain from using a psychoactive substance despite its serious effects (Cemek et al., 2011).

Cannabis is ranked as the third most utilized substance of abuse after tobacco and alcohol (Fattore et al., 2008 and Zhou et al., 2011). Ingestion of cannabis sativa derivatives, for example, weed (leaves and 
blooming tops) or janja (resin) bring about toxicity manifested by sedation, cognitive dysfunction, inability to unite transient memory, modification in time appraisal, perceptual changes, motor incoordination and poor official capacity. Studying the cannabinoid receptor-rich regions of the brain helps to know whether chronic cannabis utilization is connected with gross anatomical abnormalities or not (Murat et al., 2008).

The principle function of the endocannabinoid framework is to control synaptic neurotransmission. The endocannabinoid framework directs synaptic neurotransmission of excitatory and inhibitory circuits. The release of endocannabinoids in response to depolarization and $\mathrm{Ca} 2+$ fluxes, hinder further neurotransmitter by means of incitement of presynaptic cannabinoid receptors (Lee and Ho, 2013).

Moreover; opiate is an illicit, very addictive substance. It is both the most misused and the most quickly acting of the sedatives. Opiates (diacetylmorphine) are transformed from morphine; they impact distinctive physiological capacities in the body, including the responses of the immune system (Vasto et al., 2007).

The intricacy of the opiates' belongings disorders result from the wide appropriation of opioid receptors. These receptors have been shown on different cell sorts, including cells of both the nervous and immune systems. Opiates can consequently manage capacities of the immune system either straightforwardly by acting on the opioid receptors on lymphocytes and macrophages, or can impact the responses of the immune system through its impacts on the nervous system (Oliveira et al., 2013b).

As regard cytokines; they are discharged by white blood cells and other cells (fibroblasts, endothelial cells, epithelial cells) in the body in response to inducing stimuli. It was truth be told that cells other than those of the immune system also discharge biologically active substances, that the idea of cytokines was proposed (Cemek et al., 2011).

Cannabinoids, especially the major psychoactive component tetrahydrocannabinol, exert immunomodulatory effects that alter normal functions of $\mathrm{T}$ and B lymphocytes, natural killer cells, and macrophages in human and animals. These modulations have been observed during both in vivo and in vitro cannabinoid treatment. The molecular and cellular mechanisms for these effects are not fully defined; however, it appears that receptor as well as non receptor mechanisms are involved (Kelton, 2008).

Reactive oxygen species (ROS) are products of normal cellular metabolism. 
The majority of the body's vitality is created by the enzymatically controlled response of oxygen with hydrogen particle in oxidative phosphorylation occurring inside the mitochondria during oxidative metabolism. During this enzymatic reduction of oxygen to produce energy, free radicals are formed (Valko et al., 2007).

Opiates were shown to induce a decrease in the activities of superoxide dismutase (SOD), catalase and glutathione peroxidase (GPx) in the mouse brain (Qiusheng et al., 2005). Moreover, morphine induced a decrease in GSH levels in the rat (Guzman et al., 2006) and rabbit brains, and also a decrease in unsaturated fatty acids in the rabbit nervous system (Ozmen et al., 2007).

The aim of the present work is to investigate the oxidative stress effects of opiates and cannabis addiction and their impacts on the immune system in Egyptian population sample.

\section{SUBJECTS AND METHODS}

\section{Subjects:}

This study was conducted on 84 subjects who were admitted to Ain Shams Psychiatric Department from January 2013 to October 2013 when the targeted cases were collected. Approval from the Ethical Committee of Ain Shams Univer- sity - Faculty of Medicine was taken besides written informed consent from each subject to participate in the research. They were divided into two groups:

A. Study group: 60 male and female addicts who were diagnosed by Diagnostic and Statistical Manual of Mental Disorders (DSM-IV), 4th edition. They were further divided into 4 groups:

Group I: Male addicts to heroin ( $\mathrm{n}=$ 15).

Group II: Male addicts to cannabis ( $\mathrm{n}=$ 15).

Group III: Female addicts to heroin (n $=15)$.

Group IV: Female addicts to cannabis $(n=15)$.

B. Control group: 24 apparently healthy male and female subjects (smokers) matched by sex and age; divided into two control groups (12 each).

\section{Inclusion criteria:}

All addicts and control subjects were selected as heavy smokers (smoking more than 40 cigarettes/day, of any type of cigarettes) to neglect the effect of nicotine smoking when comparing between addict and control groups. Moreover, all addict subjects selected from the chronic ones (addict for more than 6 years).

Addicts were subjected to screening of some substance of abuse in urine 
“opiates, barbiturates, benzodiazepines, cannabis, amphetamines, and ethyl alcohol". Those who were only positive to either heroin or cannabis were included in the study.

\section{Exclusion criteria:}

Those who had diabetes, history of liver disease, unstable cardiovascular disease, infections; inflammation; peripheral vascular, respiratory, or gastrointestinal disease or a malignancy, were excluded.

\section{Sampling}

Forty $\mathrm{mL}$ urine were collected in the morning between 9 am and $12 \mathrm{pm}$ for screening of cannabis and heroin.

Four mL blood sample was collected on ethylenediaminetetraacetic acid after being sure that all subjects do not receive any treatment from the first time of admission to the time of blood sampling .

\section{Methods}

a. Screening of substance of abuse: Any turbid samples or those containing blood were excluded from the study. Catheterization was done if the patient was unable to void urine or comatose. Each sample was collected in a clean, dry and labeled container (name, serial number and date of taking the sample). It was stored frozen in the deep freezer at $-4^{\circ} \mathrm{C}$ till analysis. Qualitative analysis by Enzyme Multiplied Immunoassay Test
(EMIT) was used for preliminary detection of heroin and cannabis (Syva Solaris system, Syva Co., S/N 1067 Version 3.00 L., CA 95/35 USA).

\section{b. Measurement of reactive oxygen species (ROS):}

Blood samples were allowed to clot for 15 minutes and centrifuged at $4000 \mathrm{rpm}$ for 15 minutes. The yielded serum was aliquoted and stored at $-20{ }^{\circ} \mathrm{C}$ until the time of analysis. The separated serum was used for determination of interleukins (IL2 and IL6); protein sulfhydryl groups; thiobarbituric acid reactive substances (TBARS) and protein oxidation.

Determination of serum protein sulfhydryl groups (GSH): The protein $\mathrm{SH}-$ groups react with S-S linkage of 5, 5dithiobis (2-nitrobenzoic acid) [DNB] (Ellman,s reagent) at $\mathrm{pH} 7.4$ to yield a coloured product, 5-thio-2-nitrobenzoic acid, which could be measured colorimeterically at $412 \mathrm{~nm}$ (Koster et al., 1986).

Determination of TBARS: Lipid peroxidation products were measured in the serum using thiobarbituric acid assay modified according to the suggestions of Sushmakumari et al. (1989).

Determination of Protein oxidation: Protein oxidation was measured utilizing the interaction between 2,4-dinitrophenylhydrazine and the carbonyls generated 
from the oxidative alteration of proteins to yield a chromophore that absorbs strongly at $380 \mathrm{~nm}$ (Levine et al., 1990).

\section{c. Measurement of IL 2 and IL6 using} ELISA technique (ANOGEN Inc., Canada):

A monoclonal antibody specific for IL-2 had been pre-coated onto a microplate. Standards and samples were pipetted into the wells and any IL-2 present was bound by the immobilized antibody. After washing away any unbound substances, an enzyme-linked polyclonal antibody specific for IL-2 was added to the wells. Following a wash to remove any unbound antibody-enzyme reagent, a substrate solution was added to the wells and colour develops in proportion to the amount of IL-2 bound in the initial step. The colour development was stopped and the intensity of the color was measured (Hatakeyama and Taniguchi, 1990).

However; for IL6; the microtiter plate pre-coated with a monoclonal antibody specific to IL-6. Standards or samples were then added to microtiter plate wells with a biotin-conjugated polyclonal antibody preparation specific for IL-6 and incubated. IL-6 if present, will bind and become immobilized by the antibody pre-coated on the wells and then be "sandwiched" by biotin conjugate. Washing to remove unbound IL- 6 and other components of the sample. Avidin conjugated to horseradish peroxidase (HRP) enzyme was added to each microplate well and incubated. Avidin was a tetramer containing four identical subunits that each had a high affinitybinding site for biotin. The wells were thoroughly washed to remove all unbound HRP-conjugated avidin and tetramethylbenzidine substrate solution was added to each well. The enzyme HRP and substrate are allowed to react over a short incubation period. Only those wells that contain IL-6, biotin-conjugated antibody and enzyme-conjugated Avidin will exhibit a change in colour. The enzymesubstrate reaction was terminated by the addition of a sulphuric acid solution and the colour change was measured spectrophotometrically at a wavelength of 450 nm (Bauer and Herrmann, 1991).

\section{Statistical Analysis}

Statistical analysis of obtained data was carried out by using the GraphPad InStat and GraphPad Prism software (SanDiego, USA). The description of the data was done in the form of mean (+/-) standard error (SE) for quantitative data. The analysis of the data was done to test statistical significant difference between groups. For quantitative data, student t-test was used to compare between two groups. Repeated measure ANOVA was used to compare same group in different times. Significance was considered if $\mathrm{p} \leq 0.05$ at confidence interval $95 \%$. 


\section{RESULTS}

There was significant difference between the mean value of serum IL2 in heroin and cannabis male and female groups as compared to the control groups as shown in table (1). Furthermore; there was no significant difference between the mean value of serum IL6 in heroin and cannabis male and female groups as com- pared to the control groups (Table 2). Moreover; there was significant decrease in serum glutathione level in heroin and cannabis male and female groups as compared to the control groups (Table 3). Also; there were significant increase in both serum TBARS level and serum protein oxidation in heroin and cannabis male and female groups as compared to the control groups (Tables 4 and 5).

Table (1) : The serum level of IL2 $(\mathrm{pg} / \mathrm{mL})$ in all studied groups $(\mathrm{n}=84)$.

\begin{tabular}{|c|c|c|c|c|}
\hline Gender & Groups & $\mathbf{n}$ & Range & Mean \pm SE \\
\hline \multirow{3}{*}{ Males } & Control & 12 & $115-217.3$ & $152.4 \pm 7.33$ \\
\cline { 2 - 5 } & Heroin & 15 & $50.1-97.10$ & $64.9 \pm 2.99^{\mathbf{a}}$ \\
\cline { 2 - 5 } & Cannabis & 15 & $52.9-74.30$ & $64.45 \pm 1.70^{\mathbf{a}}$ \\
\hline \multirow{2}{*}{ Females } & Control & 12 & $130.5-218.1$ & $163.5 \pm 7.55$ \\
\cline { 2 - 5 } & Heroin & 15 & $46.70-77.60$ & $62.93 \pm 2.19^{\mathbf{b}}$ \\
\cline { 2 - 5 } & Cannabis & 15 & $46.50-79.70$ & $61.67 \pm 2.18^{\mathbf{b}}$ \\
\hline
\end{tabular}

a Significantly lower than the male control group $(\mathrm{p}<0.001)$; $\mathrm{b}$ significantly lower than the female control group $(\mathrm{p}<0.001)$; $\mathrm{SE}=$ standard error of mean; $\mathrm{n}=$ number.

Table (2) : The serum level of IL6 $(\mathrm{pg} / \mathrm{mL})$ in all studied groups $(\mathrm{n}=84)$.

\begin{tabular}{|c|c|c|c|c|}
\hline Gender & Groups & $\mathbf{n}$ & Range & Mean $\pm \mathbf{S E}$ \\
\hline \multirow{3}{*}{ Males } & Control & 12 & 14.9032 .40 & $20.67 \pm 1.28$ \\
\cline { 2 - 5 } & Heroin & 15 & 15.3024 .80 & $20.67 \pm 0.69$ \\
\cline { 2 - 5 } & Cannabis & 15 & 14.9025 .00 & $19.79 \pm 0.0 .70$ \\
\hline \multirow{2}{*}{ Females } & Control & 12 & $17.70-25.20$ & $20.80 \pm 0.66$ \\
\cline { 2 - 5 } & Heroin & 15 & 16.4023 .20 & $19.69 \pm 0.58$ \\
\cline { 2 - 5 } & Cannabis & 15 & 14.9024 .90 & $20.49 \pm 0.72$ \\
\hline
\end{tabular}

$\mathrm{SE}=$ standard error of mean; $\mathrm{n}=$ number. 
Table (3) : The serum level of glutathione $(\mu \mathrm{mol} / \mathrm{L})$ in all studied groups $(\mathrm{n}=84)$.

\begin{tabular}{|c|c|c|c|c|}
\hline Gender & Groups & $\mathbf{n}$ & Range & Mean \pm SE \\
\hline \multirow{3}{*}{ Males } & Control & 12 & $552.9-663.2$ & $605.9 \pm 9.76$ \\
\cline { 2 - 5 } & Heroin & 15 & 301.5485 .3 & $418.8 \pm 13.10^{\mathbf{a}}$ \\
\cline { 2 - 5 } & Cannabis & 15 & 327.9491 .2 & $412.9 \pm 14.35^{\mathbf{a}}$ \\
\hline \multirow{2}{*}{ Females } & Control & 12 & 545.6714 .7 & $610.5 \pm 15.21$ \\
\cline { 2 - 5 } & Heroin & 15 & 322.1486 .8 & $406.8 \pm 14.99^{\mathbf{b}}$ \\
\cline { 2 - 5 } & Cannabis & 15 & 310.3480 .9 & $408.8 \pm 14.67^{\mathbf{b}}$ \\
\hline
\end{tabular}

a Significantly lower than the male control group $(\mathrm{p}<0.001)$; $\mathrm{b}$ significantly lower than the female control group $(\mathrm{p}<0.001) ; \mathrm{SE}=$ standard error of mean; $\mathrm{n}=$ number.

Table (4) : The serum level of TBARS ( $\mathrm{mmol} / \mathrm{dL})$ in all studied groups $(\mathrm{n}=84)$.

\begin{tabular}{|c|c|c|c|c|}
\hline Gender & Groups & $\mathbf{n}$ & Range & Mean \pm SE \\
\hline \multirow{3}{*}{ Males } & Control & 12 & 0.130 .19 & $0.17 \pm 0.00$ \\
\cline { 2 - 5 } & Heroin & 15 & 0.260 .44 & $0.35+0.01^{\mathbf{a}}$ \\
\cline { 2 - 5 } & Cannabis & 15 & 0.240 .41 & $0.32 \pm 0.01^{\mathbf{a}}$ \\
\hline \multirow{3}{*}{ Females } & Control & 12 & 0.140 .19 & $0.17 \pm 0.00$ \\
\cline { 2 - 5 } & Heroin & 15 & 0.250 .43 & $0.32 \pm 0.01^{\mathbf{b}}$ \\
\cline { 2 - 5 } & Cannabis & 15 & 0.220 .37 & $0.31 \pm 0.01^{\mathbf{b}}$ \\
\hline
\end{tabular}

a Significantly higher than the male control group $(\mathrm{p}<0.001)$; $\mathrm{b}$ significantly higher than the female control group $(\mathrm{p}<0.001) ; \mathrm{SE}=$ standard error of mean; $\mathrm{n}=$ number.

Table (5) : The serum protein oxidation level $(\mu \mathrm{mol} / \mathrm{L})$ in all studied groups $(\mathrm{n}=84)$.

\begin{tabular}{|c|c|c|c|c|}
\hline Gender & Groups & $\mathbf{n}$ & Range & Mean \pm SE \\
\hline \multirow{3}{*}{ Males } & Control & 12 & 30.6871 .36 & $54.81 \pm 2.77$ \\
\cline { 2 - 5 } & Heroin & 15 & 87.73165 .9 & $121.7 \pm 6.27^{\mathrm{a}}$ \\
\cline { 2 - 5 } & Cannabis & 15 & 76.82154 .8 & $116.6+5.02^{\mathrm{a}}$ \\
\hline \multirow{2}{*}{ Females } & Control & 12 & 55.9179 .54 & $67.29 \pm 2.11$ \\
\cline { 2 - 5 } & Heroin & 15 & 84.54165 .9 & $125.0+8.04^{\mathrm{b}}$ \\
\cline { 2 - 5 } & Cannabis & 15 & 76.82163 .2 & $119.8+7.52^{\mathrm{b}}$ \\
\hline
\end{tabular}

a Significantly higher than the male control group $(\mathrm{p}<0.001)$; $\mathrm{b}$ significantly higher than the female control group $(\mathrm{p}<0.001)$; $\mathrm{SE}=$ standard error of mean; $\mathrm{n}=$ number. 


\section{DISCUSSION}

If cannabinoids or heroin is immunomodulatory, they would be expected to exert some of that effect through modulation of cytokine production and function. Cytokines assume a significant role in mediating the antimicrobial impacts of immune cells. Interferons are effective antiviral agents and also immunomodulators and IL-2 is a major growth factor for the development of immunity (Shay et al., 2003).

The present work was conducted to investigate the oxidative stress effects of heroin and cannabis addiction and their impact on the immune system. The major finding of this study is significant decrease in IL-2 level in heroin and cannabis addicts in relation to the control group; which explain increase incidence of infection that may occur in the majority of addicts. This is in agreement with results of Pacifici et al. (2003) and Shay et al. (2003). While there is no significant effects on IL-6 levels in both heroin and cannabis male and female addicts. This is on contrary to Thomas et al. (2000) and Thomas et al. (2003) who found that cannabis smoking resulted in a decrease in production of IL-6.

Cytokines assume a significant role in mediating the antimicrobial impacts of immune cells. Interleukin - 2 is a major growth factor for the development of immunity (Shay et al., 2003). Normally, T lymphocyte proliferation is dependent on IL-2 which is essential for proliferation induction. The reduction of proliferation suggests that $\mathrm{T}$ lymphocyte activation pathways are deteriorated in heroin users (Yang et al., 2013).

Furthermore; cannabinoids deteriorate immune systems (cell-mediated and humoral), decreasing resistance to infection as measured by reduced numbers or impaired functioning of T-lymphocytes, Blymphocytes or macrophages, or reduced immunoglobulin levels. These effects could be related to $\mathrm{CB} 2$ receptors which are located on immune cells (Ginaldi et al., 2004). However; morphine directly affect the immune response through opioid receptors on leukocyte and indirectly via the receptors on neuronal cells. Opiates alter the release of hypothalamus pituitary adrenal hormones thus increase susceptibility to infection (Yang et al., 2013).

Moreover; the current results revealed significant decrease in glutathione level in opiates and cannabis addicts. This is in agreement to the studies of Qiusheng et al. (2005); Guzman et al. (2006) and Ozmen et al. (2007), which could be explained by free radical-mediated oxidative activity and the generation of ROS resulting in generation of oxidized glutathione. The generation of ROS had several undesirable 
consequences, including the impairment of cellular energetic and defense systems and the promotion of malignant transformation (Shay et al., 2003; Thomas et al., 2000; Thomas et al., 2003). Cell death induced by cannabis smoke is largely necrotic. These deleterious effects of cannabis smoke could have serious implications for tissues in direct contact including lung macrophages and surface epithelial cells in the upper aerodigestive tract and the tracheobronchial mucosa (Xu et al., 2006).

In addition, the current study stated significant increase in TBARS. This is the same as those of Ozmen et al. (2007); Cemek et al. (2011) and Oliveira et al. (2013a) which revealed that opiates led to oxidative DNA damage, protein oxidation and lipid peroxidation. However, it has been extremely difficult to establish a direct cause and effect relationship between oxygen radicals' formation and the actual lesion induced by opiates and cannabis. Lipid peroxidation mediated by oxygen radicals is believed to be an important cause of destruction and damage to cell membranes, because a single stimulus can result in conversion of hundreds of fatty acid side chains into lipid peroxides, which alter the structural integrity and biochemical functions of membranes (Song et al., 2010).

Finally; the present results stated signif- icant elevation in protein oxidation levels in heroin and cannabis addicts. This suggests that the oxidation of these proteins may be an early component of the sequence of events leading to mucosal edema and inflammation which may be caused by addiction (Oliveira et al., $2013 b)$. Protein damaged by oxidation is normally degraded quickly in the cell, but in cell where degradative protease activity is overwhelmed or lost by inactivation or decreased production, the oxidized proteins accumulates as in aging, diabetes, and inflammation. The accumulation of oxidized proteins can impair cell function and eventually lead to cell damage. Therefore, protein oxidation may be an early sign of cellular injury (Vergeade et al., 2012).

\section{CONCLUSION}

From the present work it could be concluded that heroin and cannabis addiction had deleterious effects on the immune system may be through their effects on oxidative stress and release of ROS and as long consequences may lead to development of bronchogenic carcinoma.

\section{REFERENCES}

Bauer, J. and Herrmann, F. (1991): "Interleukin - 6 in clinical medicine". Ann. Hematology, 62: 203-213. 
Cemek, M.; Buyukokuroglu, M.E.; Hazman, O.; et al. (2011): “The roles of melatonin and vitamin $\mathrm{E}$ plus selenium in prevention of oxidative stress induced by naloxone precipitated withdrawal in heroin-addicted rats". Biol. Trace Elem. Res., 142 (1): 55-66.

Fattore, L.; Fadda. P.; Spano, M. S.; et al. (2008): "Neurobiological mechanisms of cannabinoid addiction". Molecular and Cellular Endocrinology, 286: 97-107.

Ginaldi, L.; De Martinis, M.; Monti, D. and Franceschi, C. (2004): "The immune system in the elderly. Activation-induced and damage induced apoptosis". Immunologic Res., 30:81-94.

Guzman, D.C.; Vazquez, I.E.; Brizuela, N.O.; et al. (2006): "Assessment of oxidative damage induced by acute doses of morphine sulfate in postnatal and adult rat brain". Neurochem. Res., 31(4): 549554.

Hatakeyama, M. and Taniguchi, T. (1990): Interleukin-2. In: Peptide Growth Factors and Their Receptors. SpringerVerlag, New York, P. 523.

Kelton, T. (2008): "Oxidative stress and male infertility - a clinical perspective". Human Reproduction Update, 14: 243-258.
Koster, J.F.; Biemond, P. and Swaak, A.J. (1986): "Intracellular and extracellular sulphydryl levels in rheumatoid arthritis". Annals of the Rheumatic Diseases, 45:44-46.

Lee, C.W.S. and Ho, I.K. (2013): “Sex differences in opioid analgesia and addiction: interactions among opioid receptors and estrogen receptors". Lee and Ho Molecular Pain, 9 :45-55.

Levine, R.L.; Garland, D.; Oliver, C.N.; et al. (1990): "Determination of carbonyl content in oxidatively modified proteins". Methods Enzymol., 186: 464-478.

Murat, Y.; Nadia, S.; Colleen, R.; et al. (2008): “Regional brain abnormalities associated with long-term heavy cannabis use". Arch. Gen. Psychiatry, 65(6): 694701.

Oliveira, T.C.; Rego, A.C. and Oliveira, C.R. (2013a): “Oxidative stress and drugs of abuse: An update". Mini-Reviews in Organic Chemistry, 10(4): 1-13.

Oliveira, T.C.; Silva, L.; Silva, A.M.; et al. (2013b): "Mitochondrial complex I dysfunction induced by cocaine and cocaine plus morphine in brain and liver mitochondria". Toxicol. Lett., 219 (3):298-306.

Ozmen, I.; Naziroglu, M.; Alici, H.A.; et al. (2007): "Spinal morphine administra- 
tion reduces the fatty acid contents in spinal cord and brain by increasing oxidative stress". Neurochem. Res., 32(1):19-25.

Pacifici, R.; Zuccaro, P. and Pichini, S. (2003): "Modulation of the immune system in cannabis users". J.A.M.A., 289 (15):1929-1931.

\section{Qiusheng, Z.; Yuntao, Z.; Rongliang} Z.; et al. (2005): "Effects of verbascoside and luteolin on oxidative damage in brain of heroin treated mice". Pharmazie, 60 (7):539-543.

Shay, A.H.; Choi, R.; Whittaker, K.; et al. (2003): "Impairment of antimicrobial activity and nitric oxide production in alveolar macrophages from smokers of marijuana and cocaine". J. Infect. Dis., 187:700-704.

Song, B.J.; Moon, K.H.; Upreti, V.V.; et al. (2010): "Mechanisms of MDMA (ecstasy)-induced oxidative stress, mitochondrial dysfunction, and organ damage". Curr. Pharm. Biotechnol., 11(5): 434-443.

Sushmakumari, S.; Jaydeep, A.; Kumar, J. S. and Menon, V. P. (1989): "Effect of carnitine on malonyldialdehyde, taurine and glutathione levels in heart of rats subjected to myocardial stress by isoprotenol". Indian J. Exp. Biol., 27: 134-137.
Thomas, W.K.; Brian, L.; Catherine, A.N. and Herman, F. (2000): "The cannabinoid system and cytokine network". Proceedings of the Society for Experimental Biology and Medicine, 225:1-8.

Thomas, W.K.; Cathy, N.; Kellie, L.; et al. (2003): "The cannabinoid system and immune modulation". Journal of Leukocyte Biology, 74:486-496.

Valko, M.; Leibfritz, D.; Moncol, J.; et al. (2007): "Free radicals and antioxidants in normal physiological functions and human disease". Int. J. Biochem. Cell Biol., 39:44-84.

Vasto, S.; Grimaldi, M.P.; Caruso, C.; et al. (2007): "Inflammatory networks in ageing, age related diseases and longevity". Mech. Ageing and Development, 128:83-91.

Vergeade, A.; Mulder, P.; Vendeville, C.; et al. (2012): "Xanthine oxidase contributes to mitochondrial ROS generation in an experimental model of cocaine- induced diastolic dysfunction". J. Cardiovasc. Pharmacol., 60 (6):538-543.

Xu, B.; Wang, Z.; Li, G.; et al. (2006): "Heroin-administered mice involved in oxidative stress and exogenous antioxidant-alleviated withdrawal syndrome" Basic Clin. Pharmacol. Toxicol., 99:153 161. 
Yang, Y.; Bazhin, A.V.; Werner, J. and Karakhanova, S. (2013): "Reactive oxygen species in the immune system". Int. Rev. Immunol., 32:249-270.
Zhou, J.; Li, Y.; Yan, G.; et al. (2011): "Protective role of taurine against morphine-induced neurotoxicity in C6 cells via inhibition of oxidative stress". Neurotox. Res., 20(4):334-342. 


\title{
الإجهاد التأكسدى لإدمان الهروين والششيش في عينه عن الهصريين
}

\author{
المشتركون فى البحث
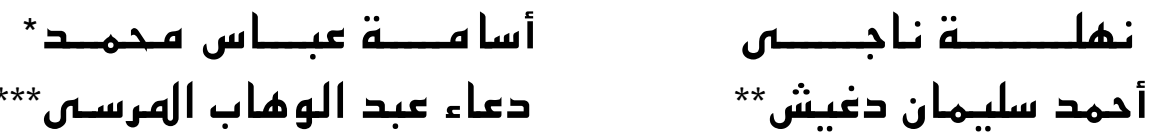 \\ أقسام الأمراض النفسية والأدوية والعلاج* - كلية الطب - جامعة عين شمس \\ الكيمياء الحيوية** - كلية الصيدلة - جامعة الأزهـــ \\ الطب الشرعي والسموم الاكلينيكيه*** - كلية الطب - جامعة المنصورة - مصر
}

يتناول هذا البحث دراسة السيتوكينات وتأثير الإجهاد التأكسدى في عينة من المصريـين المدمنين للحشـيش و الهروين. و قد أجريت هذه


وحتى الثامنة والثلاثين عام. وقد قسمت إلى ستة مجموعات كما يلي:-

المجموعة الأولى: وتشمل خمسة عشر من الذكورالمدمنين للهروين.المجمموعة الثانية: وتشمل خمسة عشر من الذكورالمدمنين للحشيش.

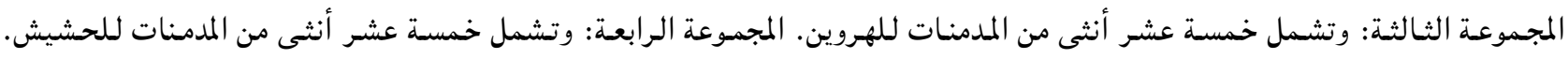

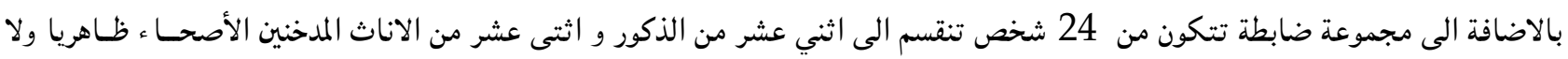

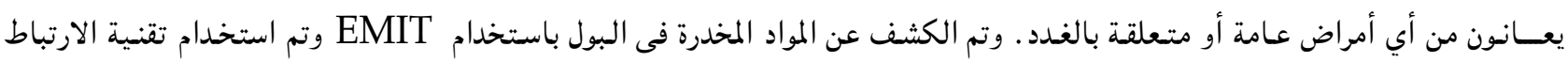

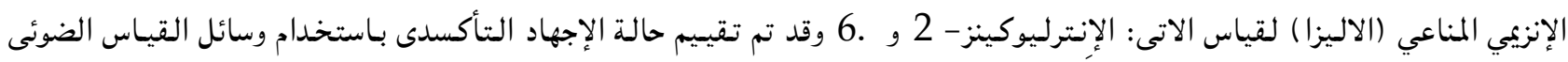
الطيفى لقياس مستوى الجلوتاثيون المختزل فى الأنسجة رقياس مستوى الأكسدة الفوقية للدهنيات روقياس مستوى الأكسدة للبروتينات. وتتلخص نتائج الدراسة فى الاتى: انخفاض مستوى كلا من الإنترلوكين- 2 و الجلوتاثيون المختزل إنخفاضاً ذو دلالة احصائية فى كلا من

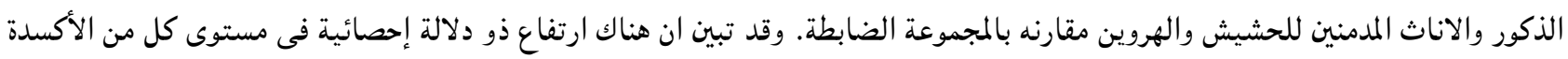

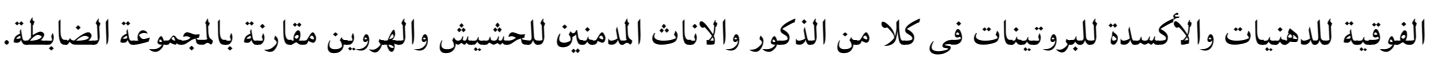
ويككن من هذه الدراسة استخلاص الاتى: أن الاستخدام الخاطئ للهروين والحشيش يؤدى الى تعديل الأداء الوظيفي للمناعة و السيتوكينات

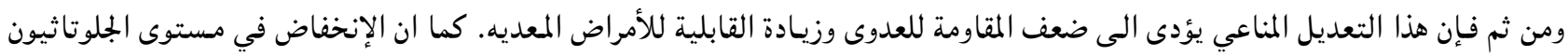

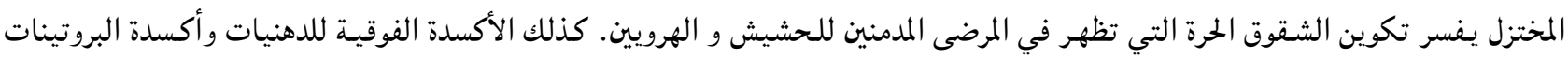

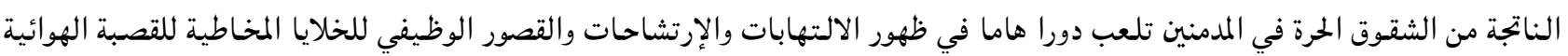



